\title{
THE IMPACT OF THE MORPHOLOGY OF MOUNTAIN WATERCOURSES ON THE HABITAT PREFERENCES INDICATED BY ICHTYOFAUNA USING THE IFIM METHODOLOGY
}

\author{
ŠTEFUNKOVÁ, Z. ${ }^{1 *}$ - BELČÁKOVÁ, I. $^{2}$ - MAJOROŠOVÁ, M. ${ }^{1}$ - ŠKRINÁR, A. ${ }^{1}$ - VASEKOVÁ, B. ${ }^{1}$ - \\ NERUDA, $\mathrm{M}^{3}{ }^{3}$ - MACURA, V. ${ }^{1}$ \\ ${ }^{1}$ Faculty of Civil Engineering, Slovak University of Technology in Bratislava \\ Radlinského 11, 81005 Bratislava, Slovakia \\ (phone: +421-2-5927-4471; fax: +421-2-5296-7027) \\ ${ }^{2}$ Faculty of Ecology and Environmental Sciences, Technical University in Zvolen \\ T. G. Masaryka 24, 96053 Zvolen, Slovakia \\ (phone: +421-455-206-492; fax: +421-455-206-279 \\ ${ }^{3}$ Faculty of Environment, Jan Evangelist Purkkyně University in Ústi nad Labem \\ Králova Výšina 3132/7, 40096 Ústí nad Labem, Czech Republic \\ (phone: +420-739-335-079; fax: +420-475-284-158) \\ *Corresponding author \\ e-mail: zuzana_stefunkova@stuba.sk; phone: +421-2-5927-4617; fax: +421-2-5292-3575 \\ (Received $4^{\text {th }}$ Jun 2018; accepted $14^{\text {th }}$ Aug 2018)
}

\begin{abstract}
A natural channel differs from a prismatic one by its rich variability. Regulated rivers have a geometrically regular shape that is not suitable for the instream biota. The morphology of a regulated river is the main cause of habitat changes. The article provides the results of research that was focused on assessing the impact of a channel's morphology on the instream habitat preferences by ichthyofauna. In the article the ichthyofauna is represented by brown trout (Salmo trutta $\mathrm{m}$. fario). During the years 2015 and 2016, research was carried out for 13 reaches of mountain watercourses in Slovakia. These reaches were geodetically measured, and a hydraulic model was created. The ichthyological survey was focused on the fish's habitat preferences. A set of data was created from the results that was statistically evaluated by cluster analysis, and the correlation relations for the abiotic and biotic characteristics of the watercourses were evaluated. The individual evaluations provide mutually compatible results. It can be concluded from the results that bioindications by fish provide reliable results in relationship to the changes in habitats in regulated rivers. There was an unambiguous statistical correlation in the preferences of brown trout in the regulated and natural rivers.
\end{abstract}

Keywords: brown trout, suitability curves, RHABSIM, river regulation effect

\section{Introduction}

In most cases, the regulation of rivers has always been and is still oriented towards flood protection. Often, such implementation has been unilaterally aimed at increasing the capacity of the channel, so that the variability of the channel's morphology was replaced by a prismatic shape. Such modifications significantly altered the natural morphology of the channel. Natural habitats that create favorable conditions for biota during minimum flows have disappeared in regulated rivers. Therefore, a whole set of methodologies that assess the consequences of changes in rivers has been developed. 
Modelling of the biological variables of a stream was used for this purpose. This method enable an assessment of the suitability of the microhabitat of a reach (Copp, 1992; Bockelmann et al., 2004), the organization of aquatic communities (Townsend and Hildrew, 1994) or the anthropogenic impact on a watercourse (Shuler and Nehring, 1994; Shields et al., 1997).

A key aspect of these methodologies is to identify and assess the links between the hydromorphological, physical-chemical and biological states of streams (Conallin et al., 2010; Galie et al., 2017).

Along with the quality of streams and biotic interactions, morphological characteristics form a basis for assessing the availability of a habitat (Carnie et al., 2016; Gibson and Pasternack, 2016). When restoring the regulations that were aimed only on flood protection, it is important to be able to predict the response of the biota to the restoration measures. Therefore, the modelling of the impact of the morphology on a river's ecosystem requires a systematic and repeatable analysis of the impacts of the habitat characteristics of the stream on its suitability (Galbraith et al., 2016; Turner et al., 2016), the organization of aquatic compartments (Piniewski et al., 2016), and any anthropogenic changes in the stream (Santiago et al., 2016). This is the methodological framework for an environmental assessment of the effects of changes in streams (climatic, morphological, quality of water, etc.), on the quality of the aquatic habitat that are based on the Instream Flow Incremental Methodology - IFIM (Bovee, 1982; Bovee et al., 1998).

The impact of changes of the quality of a habitat is determined by bioindications. Research shows that freshwater fish are good indicators of morphological changes in streams and of biotic integrity in freshwater ecosystems (Pont et al., 2006; Cheek et al., 2016; Roni et al., 2014). They also respond sensitively to changes in the temperature and flow (Avery-Gomm et al., 2014). Due to their mobility, which they also have in their old age, and sensitivity to biotope changes, fish are suitable for assessing a river's ecological integrity (Keeley et al., 2015; Booker and Dunbar, 2004).

Information about the impact of channel characteristics on the quality of a habitat is important. This problem was solved by Holm et al. (2001), when he created three different suitability curves of flow velocity at three different flow rates for juvenile Atlantic salmon (Salmo salar) under laboratory conditions. Holm's study focused on fish habitat preferences in terms of changes in flow, depth and velocity (see also Marsili-Libelli et al., 2013; Ayllón et al., 2009; Macura et al., 2016).

Intensive discussions are ongoing among water managers, ichthyologists and hydrobiologists. Nowadays, these specialists believe that the success or failure of any restoration project depends on understanding of river biotopes (Zhang et al., 2016) and continuous stream monitoring.

In view of this trend, the results in this article are aimed at assessing the impact of the river regulation on the quality of the aquatic habitat, which is indicated by ichthyofauna.

At present, it can be said that the success or failure of any restoration project does not only depend on continuous river monitoring; it also particularly depends on a design based on a high-quality forecast of the reaction of the biotope to the restoration interventions that will be needed. This procedure minimizes inappropriate restoration measures in a stream. In accordance with this trend, the 
results presented in this article are aimed on the impact of river regulation on the quality of an aquatic habitat that is mainly indicated by brown trout.

\section{Materials and methods}

From the point of view of the restoration of a river, it is important to quantify its design parameters. It is important to focus on the summer season. Minimum flows along with high temperatures create the highest load factors for the biota. Therefore, the summer period can be considered as a design condition for assessing the quality of a habitat or for the design of appropriate parameters for restoration measures for a river (Carlson et al., 2015; Macura et al., 2016).

The main objective was to determine the effect of the morphology of a river on the habitat preferences of the ichthyofauna, which in this article is represented by brown trout. The following methodology was selected:

- Selection of the reference reaches

- Ichthyological survey and hydrometric measurements

- Topographic measurements of the reference reaches

- Statistical evaluation of the characteristic parameters of the aquatic habitat

- Modelling of the quality of the aquatic habitat

- Effect of the flow velocity and channel depth on the suitability of the river habitat

\section{Reference reaches of the rivers}

For this study smaller mountain and piedmont streams were selected for the following reasons:

- Mountain streams have more characteristics in common, so the negative effects of their regulation are also common in many areas. Therefore, it can be expected that the results obtained could be generalized

- Mountain streams are in the upper sections of a river basin. Their length is relatively short, so the pollution load is low, and the water quality is usually suitable for the full use of the restoring effect on the stream and its surroundings.

- River regulations mainly affect the morphology of a stream. The good water quality of the selected reaches of mountain and piedmont streams does not alter the impact of the morphology on the quality of the aquatic habitat.

The reference reaches with a river basin of a size of $10-100 \mathrm{~km}^{2}$ were selected from a whole database of reference reaches by a selective method in the environment of ArcView GIS. From the point of view of the rock complexes, a flysch was selected. At this selection stage, the river basin database contained 265 river basins that fulfilled the previous conditions. In the first phase, streams where hydrological stations are located were selected. Based on the ArcView GIS analysis, a physical survey of the streams was performed, and suitable representative reaches for ichthyological and hydrometrical field measurements were selected. The Teplička, Lesnianka, Petrovička, Zázrivka, Veselianka, Kl'ačianka, Hybica, Lipnik and Kamienka reaches, which are located in the Váh River basin in Slovakia, were selected (Fig. 1 and Table 1). 


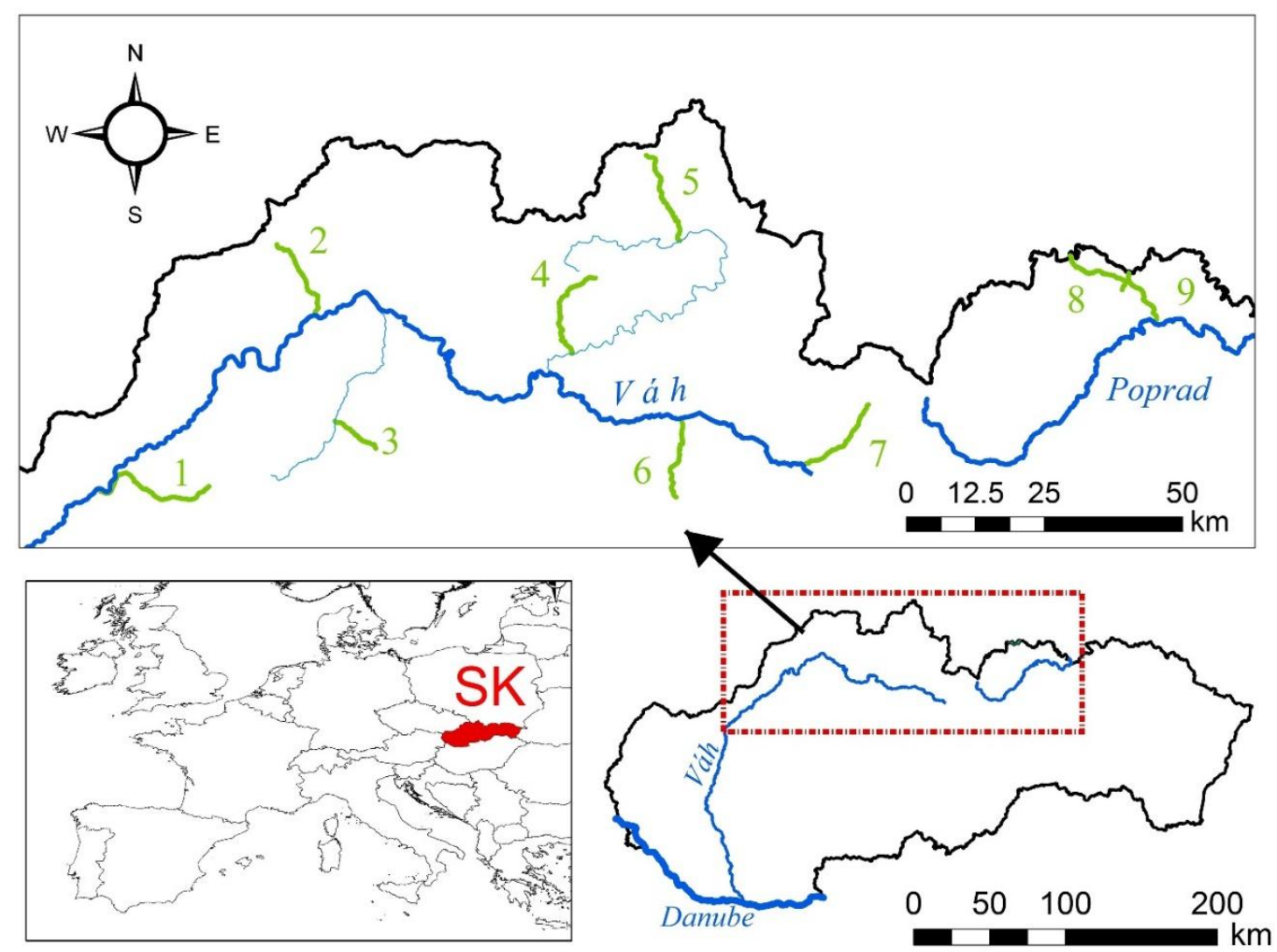

Figure 1. Localization of the reference reaches of the mountain streams in Slovakia: 1 Teplička, 2 - Lesnianka, 3 - Petrovička, 4 -Zázrivka, 5 - Veselianka, 6 - Kl’ačianka, 7 - Hybica, 8 - Lipnik, 9 - Kamienka

Table 1. WGS84 coordinates of the reference reaches. Stream condition: $N$ - Natural stream, $R$ - Regulated reach

\begin{tabular}{c|c|c|c}
\hline \multirow{2}{*}{ Teplička } & $\mathrm{N}$ & $48^{\circ} 55.169^{\prime} \mathrm{N}$ & $18^{\circ} 08.687^{\prime} \mathrm{E}$ \\
& $\mathrm{R}$ & $49^{\circ} 17.364^{\prime} \mathrm{N}$ & $18^{\circ} 47.809^{\prime} \mathrm{E}$ \\
\hline \multirow{2}{*}{ Lesnianka } & $\mathrm{N}$ & $49^{\circ} 02.246^{\prime} \mathrm{N}$ & $18^{\circ} 39.422^{\prime} \mathrm{E}$ \\
& $\mathrm{R}$ & $49^{\circ} 02.715^{\prime} \mathrm{N}$ & $18^{\circ} 37.563^{\prime} \mathrm{E}$ \\
\hline \multirow{2}{*}{ Petrovička } & $\mathrm{N}$ & $49^{\circ} 14.679^{\prime} \mathrm{N}$ & $18^{\circ} 33.100^{\prime} \mathrm{E}$ \\
& $\mathrm{R}$ & $49^{\circ} 15.366^{\prime} \mathrm{N}$ & $18^{\circ} 31.713^{\prime} \mathrm{E}$ \\
\hline \multirow{2}{*}{ Zázrivka } & $\mathrm{N}$ & $49^{\circ} 14.469^{\prime} \mathrm{N}$ & $19^{\circ} 09.328^{\prime} \mathrm{E}$ \\
& $\mathrm{R}$ & $49^{\circ} 11.351^{\prime} \mathrm{N}$ & $19^{\circ} 11.521^{\prime} \mathrm{E}$ \\
\hline \multirow{2}{*}{ Veselianka } & $\mathrm{N}$ & $49^{\circ} 26.192^{\prime} \mathrm{N}$ & $19^{\circ} 24.294^{\prime} \mathrm{E}$ \\
& $\mathrm{R}$ & $49^{\circ} 24.867^{\prime} \mathrm{N}$ & $19^{\circ} 25.965^{\prime} \mathrm{E}$ \\
\hline Klačianka & $\mathrm{N}$ & $49^{\circ} 04.611^{\prime} \mathrm{N}$ & $19^{\circ} 28.679^{\prime} \mathrm{E}$ \\
\hline \multirow{2}{*}{ Hybica } & $\mathrm{N}$ & $49^{\circ} 02.146^{\prime} \mathrm{N}$ & $19^{\circ} 47.526^{\prime} \mathrm{E}$ \\
& $\mathrm{R}$ & $49^{\circ} 02.654^{\prime} \mathrm{N}$ & $19^{\circ} 49.5744^{\prime} \mathrm{E}$ \\
\hline \multirow{2}{*}{ Lipník } & $\mathrm{N}$ & $49^{\circ} 22.439^{\prime} \mathrm{N}$ & $20^{\circ} 28.256^{\prime} \mathrm{E}$ \\
& $\mathrm{R}$ & $49^{\circ} 22.883^{\prime} \mathrm{N}$ & $20^{\circ} 26.374^{\prime} \mathrm{E}$ \\
\hline \multirow{2}{*}{ Kamienka } & $\mathrm{N}$ & $49^{\circ} 20.745^{\prime} \mathrm{N}$ & $20^{\circ} 36.221^{\prime} \mathrm{E}$ \\
& $\mathrm{R}$ & $49^{\circ} 18.091^{\prime} \mathrm{N}$ & $20^{\circ} 38.314^{\prime} \mathrm{E}$ \\
\hline
\end{tabular}




\section{Ichthyological survey}

An ichthyological survey of the selected reaches was oriented towards determining the suitability curves of the individual fish species. The data were obtained by electro fishing, similarly as in Lamouroux et al. (1999). An electrofishing device (Hans-Grassl ELT62IIHI) with the possibility of a choice of electric parameters was used to capture the fish. The parameters of the electrofishing device were determined based on the conductivity of the water and the fish species but were also based on the sensitivity of the fish to the electric current similarly as in Scholten (2003). Each part where the individual species were found has been described (Lambert and Hanson, 1989). At the capture point of each fish, the depth of the flow, the microhabitat characteristics, and the flow rate, which was measured by a set of hydrometric propellers, were recorded; three hydrometric propellers were placed on one rod. The velocities were measured as standard in the following depths of water $(d): 0.2 d, 0.4 d, 0.8 d$. Using these measured flow velocities, the mean vertical velocity was derived. Based on the mean vertical velocity, the suitability curve was created. The ichthyological survey was carried out in July 2015 and June 2016. Table 2 shows the number of fish caught in particular reaches.

\section{Topographic measurement of the reference reaches}

The topographic measurement of the various reaches was adapted to the requirements of the hydraulic modelling. The cross-section profiles were measured by levelling. The water level was fixed in characteristic profiles to stable points that accelerate the measurement of the water level mode at other flow rates. The topographic and hydrometric measurements were carried out in September 2015 in a period of minimum flow rates.

\section{Modelling of the quality of the aquatic habitat}

Based on the technical interventions in the stream, the quality of the aquatic habitat was assessed by the Instream Flow Incremental Methodology (IFIM). This method is used for an analysis of the relationship between the flow rate and biotic components of an environment, while this relationship is a continuous function of the flow rate (Williams, 2001; Lopes et al., 2004). The IFIM methodology (Bovee et al., 1998) is traditionally considered to be state of the art despite persistent criticism (Rosenfeld and Ptolemy, 2012). Based on this methodology, a number of models have been created. The Riverine Habitat Simulation Model (RHABSIM) was used. It is an interdisciplinary decision-making system that helps landscape engineers consider the benefits and consequences of different water management solutions. This model is widely used not only in the region of its creation (Payne, 1998) but also in many European countries (e.g., the U.K., Norway, and France, and often with certain modifications). A very good overview of the overall philosophy, history, development and background of the IFIM, including a comprehensive list of the literature, can be found in Stalnaker et al. (1995). The model contains data from the biotic and abiotic areas. The abiotic parameters are the width, depth and surface area of the channel, the velocity of the flow, and the hydraulic characteristics in relation to the flow and morphology of the channel. The biotic information is mainly represented by bioindicators (fish) in the form of suitability curves. The relationship of the basic characteristics of the channel (depth and flow velocity) was statistically evaluated in the first phase. 


$$
\text { - } 5898 \text { - }
$$

Table 2. The number of fish caught in particular reaches. Stream condition: $N$ - Natural stream, $R$ - Regulated reach

\begin{tabular}{|c|c|c|c|c|c|c|c|c|c|c|c|c|c|c|c|c|c|c|c|}
\hline \multirow{2}{*}{ 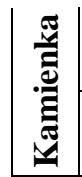 } & $\simeq$ & $\stackrel{0}{+}$ & \multirow{7}{*}{\multicolumn{2}{|c|}{ 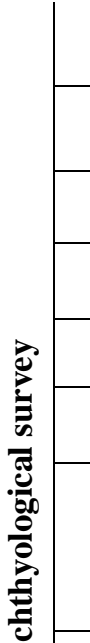 }} & in & 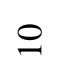 & ' & ' & ' & ' & & & ' & ' & ' & t & $\stackrel{\infty}{-}$ & $\stackrel{2}{ }$ & $\nabla$ \\
\hline & z & $\cong$ & & & $\Xi$ & फे & ' & ' & ' & ' & $a$ & & ' & ' & ' & $N$ & $\stackrel{\infty}{\sim}$ & $a$ & 으 \\
\hline \multirow{2}{*}{ 兽 } & $\simeq$ & ิㅗ & & & $\bar{m}$ & $\stackrel{\bullet}{0}$ & ' & ' & ' & ' & & & ' & ' & ' & ' & $\simeq$ & $\stackrel{\infty}{m}$ & 0 \\
\hline & z & $\infty$ & & & $\sim$ & - & ' & ' & ' & 1 & - & & ' & ' & 1 & ' & $\stackrel{\infty}{-}$ & $r$ & $n$ \\
\hline \multirow{2}{*}{ 䔅 } & $\simeq$ & $\stackrel{\overbrace{}}{=}$ & & & ' & 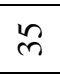 & 1 & ' & ' & ' & $\nabla$ & - & ' & ' & 1 & ' & \pm & $\underline{\ddots}$ & \\
\hline & $z$ & $\Xi$ & & & ' & $\curvearrowright$ & ' & ' & 1 & ' & I & - & ' & ' & ' & ' & $\tilde{\lambda}$ & 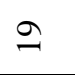 & ' \\
\hline \multirow{3}{*}{ 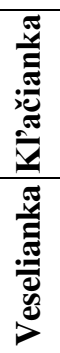 } & z & ֻొ & & & ' & ' & ' & ' & ' & ' & ' & ' & ' & ' & ' & ' & ปี & $\stackrel{m}{n}$ & \\
\hline & $\simeq$ & $\stackrel{?}{ \pm}$ & 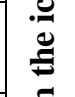 & $\because$ & $\tilde{m}$ & $\stackrel{\infty}{+}$ & ' & 0 & ' & ' & - & ' & $a$ & $N$ & ' & ' & \pm & $\stackrel{\mathcal{F}}{f}$ & \\
\hline & Z & 8 & 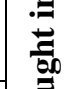 & ชิ & $\stackrel{+}{\Delta}$ & 5 & ' & - & $n$ & ' & & ' & $=$ & $R$ & ' & ' & $\stackrel{i}{ }$ & 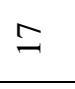 & $a$ \\
\hline \multirow{2}{*}{ 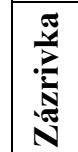 } & $\simeq$ & $\stackrel{\infty}{\varrho}$ & $\underset{\tilde{J}}{\overline{0}}$ & ' & $\stackrel{\Xi}{\sim}$ & $\tilde{n}$ & ' & ' & ' & ' & in & ' & ' & ' & $\sim$ & $\hat{\imath}$ & $\mathscr{0}$ & $\stackrel{\infty}{-}$ & - \\
\hline & $z$ & 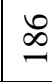 & $\stackrel{n}{0}$ & ' & ' & $\mathscr{f}$ & ' & ' & ' & ' & $=$ & ' & ' & ' & ' & ' & $\bar{n}$ & 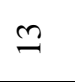 & ' \\
\hline \multirow{4}{*}{ 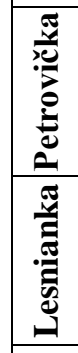 } & $\simeq$ & లి & $\begin{array}{l}\dot{\bar{\Xi}} \\
\dot{\Xi}\end{array}$ & ' & ' & 8 & ' & ' & ' & ' & & 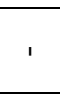 & ' & ' & ' & ' & $\cong$ & $\stackrel{\varrho}{0}$ & f \\
\hline & $z$ & $\stackrel{n}{=}$ & $\begin{array}{l}\vec{\Xi} \\
\underline{\Xi}\end{array}$ & ' & $n$ & - & ' & ' & ' & ' & & ' & ' & ' & ' & ' & $\hat{\imath}$ & \pm & $\widetilde{\sigma}$ \\
\hline & $\simeq$ & $\stackrel{\cap}{n}$ & & ' & - & ळे & ' & ' & ' & ' & & & ' & ' & ' & ' & $\underline{0}$ & $\vec{\sim}$ & \\
\hline & z & $\stackrel{\infty}{=}$ & & ' & ' & ず & ' & ' & ' & ' & & & ' & ' & ' & ' & i & 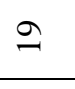 & \\
\hline \multirow{2}{*}{ 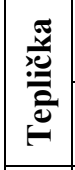 } & $\simeq$ & $\widetilde{\sigma}$ & & & $\stackrel{\infty}{\sim}$ & & Әे & $\stackrel{ \pm}{n}$ & ' & ' & & & ' & ' & ' & ' & \pm & $\vec{\sim}$ & in \\
\hline & z & $\stackrel{\curvearrowleft}{\beth}$ & & - & $\stackrel{\infty}{\longrightarrow}$ & ' & $\vec{\sim}$ & ปี & ' & $\sim$ & 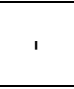 & & ' & 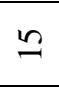 & 1 & ' & 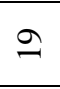 & $\stackrel{\infty}{=}$ & 0 \\
\hline \multirow[t]{2}{*}{ 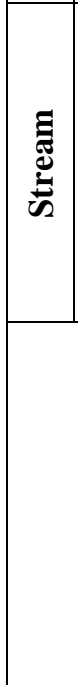 } & 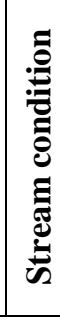 & 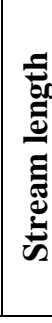 & 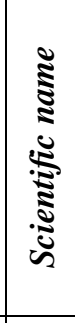 & 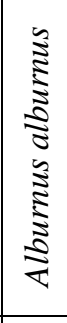 & 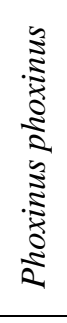 & 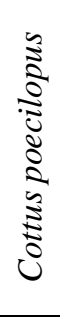 & $\begin{array}{l}: \\
: 0 \\
80 \\
: 0 \\
0 \\
0\end{array}$ & 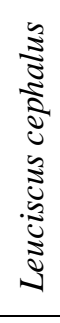 & 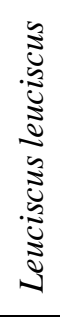 & 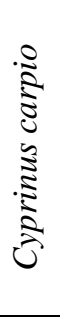 & 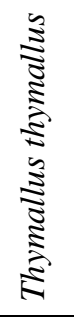 & 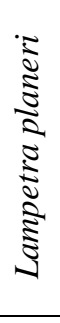 & 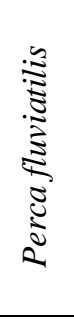 & 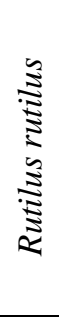 & $\begin{array}{l}\vdots \\
\vdots \\
\vdots \\
\vdots \\
\vdots \\
\vdots \\
\vdots \\
0 \\
0 \\
\vdots \\
\vdots \\
0 \\
0\end{array}$ & 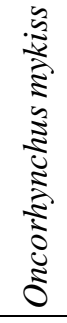 & $\begin{array}{c}5 \\
0 \\
0 \\
0 \\
0 \\
0 \\
0 \\
0 \\
0 \\
0 \\
0 \\
0 \\
0\end{array}$ & 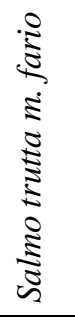 & 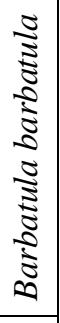 \\
\hline & & & 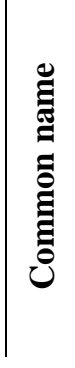 & $\frac{\frac{u}{\widetilde{J}}}{m}$ & 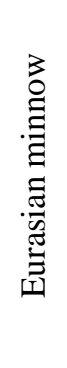 & 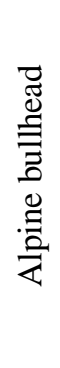 & $\begin{array}{l}\tilde{0} \\
\mathbb{0} \\
\stackrel{60}{0} \\
\tilde{J}\end{array}$ & 竎 & 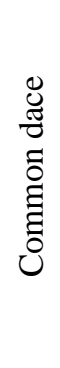 & $\begin{array}{l}\text { : } \\
0 \\
\tilde{\Xi} \\
\vdots \\
\vdots \\
0 \\
0\end{array}$ & 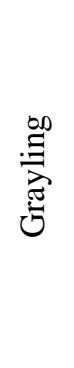 & 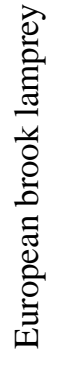 & 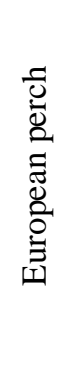 & $\begin{array}{l}\overline{0} \\
\widetilde{0} \\
\simeq\end{array}$ & 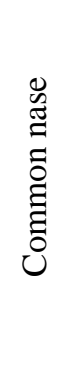 & 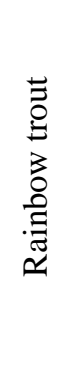 & 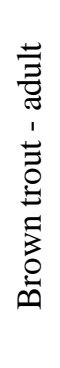 & 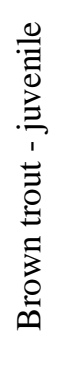 & 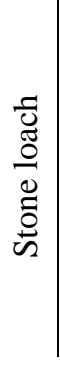 \\
\hline
\end{tabular}




\section{Results}

\section{Statistical evaluation of the characteristic parameters of the aquatic habitat}

At the point of the capture of each individual fish of the species, the depth and flow velocity were measured. The flow velocity and depth of the stream preferences were indicated by three fish species, i.e., the brown trout (Salmo trutta m. fario), Alpine bullhead (Cottus poecilopus) and Eurasian minnow (Phoxinus phoxinus). A graph of the habitat preferences for the individual fish species (Fig. 2) was developed. According to Figure 2, there is no significant difference between habitat preferences of individual fish species.

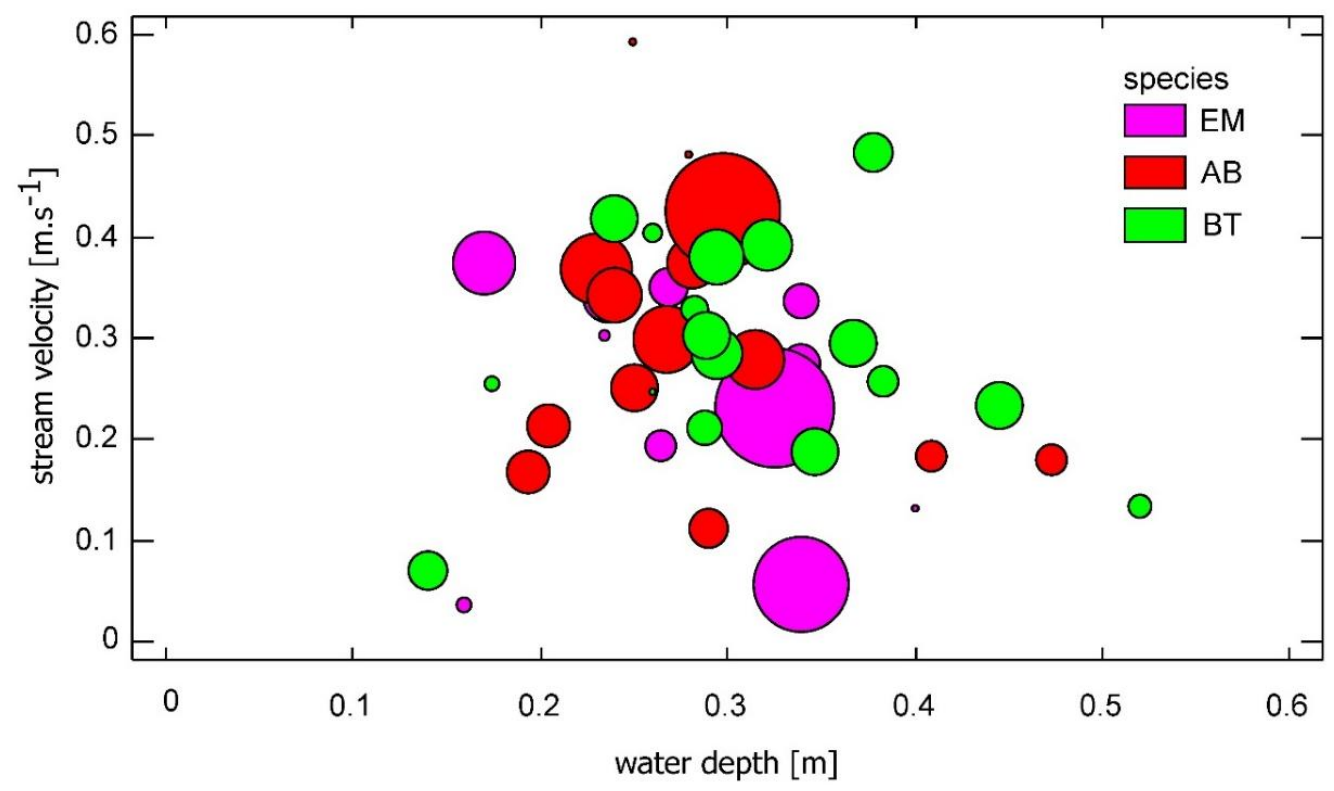

Figure 2. The graph shows the presence of the Eurasian minnow (EM), Alpine bullhead (AB) and brown trout (BT) at individual depths and flow velocities

For the next analysis the cluster method of the furthest neighbour was used. (Horváth and Gregušová, 1999).

The file was divided into two subsets, i.e., regulated and natural streams, to verify the cluster analysis results. Data on the depth, flow velocity and number of individual fish species were used as variables. Specifically, the brown trout was singled out. The number of complete cases in the cluster analysis was seventeen for the brown trout. Figure 3 clearly shows the process of the merging of the objects into clusters. The objects that were joined at the bottom of the chart are similar; those objects that are linked at the top are different. Two clusters were created:

1) Hybica N, Veselianka N, Kamienka N, Lesnianka N, Lipnik N, Teplička N and Kamienka $\mathrm{R}$, which can be described as a cluster of natural $(\mathrm{N})$ reaches.

2) Hybica R, Petrovička R, Petrovička N, Teplička R, Kl'ačianka R, Zázrivka N, Lesnianka R, Lipník R, Veselianka $\mathrm{R}$ and Zázrivka $\mathrm{R}$, which can be described as a cluster of regulated $(R)$ reaches.

On a vertical axis, the distance between the individual objects is displayed where this distance is defined as the centroid distance of the two clusters. Centroid is a vector of diameters (each coordinate is the diameter of the respective coordinate objects in the 
cluster). The method was derived by R. R. Sokal and C. D. Michener (1958) based on the geometric concepts and the degree of disparity of the two clusters was expressed as the Euclidean distance of their drawings.

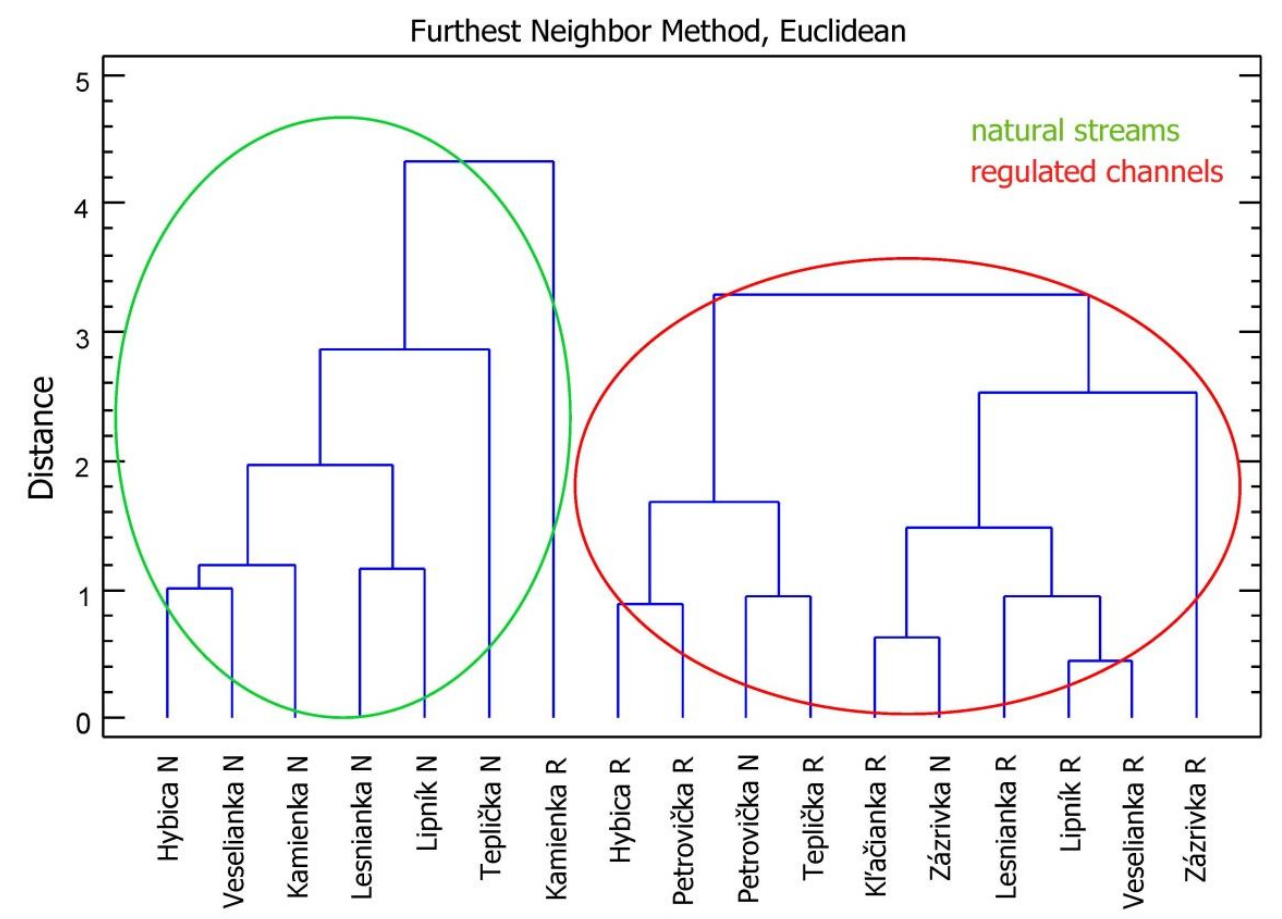

Figure 3. Dendrogram of brown trout. The vertical axis represents the distance between the individual objects. Stream condition: $N$ - Natural stream, $R$ - Regulated reach

This division is not perfect because the regulated reach of Kamienka is included in the group of natural reaches, but it is attached at the top of the dendrogram, which shows a certain difference from this group. Also, there are two natural reaches in the cluster of regulated reaches. The reason for this classification is the fact that the morphology of these reaches is poorly variable and therefore little different from the regulated reach.

Figure 4 shows the division of the individual reaches into clusters that focus on the distance between the objects. The objects located at the edge of the cluster are the most remote and therefore the least alike. This difference is evident in the Kamienka flow.

The next analysis will be based on the preference of the brown trout as expressed by the suitability curves that are the basic input to the RHABSIM model.

\section{Derivation of the suitability curves}

In the RHABSIM model, the basic parameters of a river habitat are divided into abiotic and biotic parameters. The biotic parameters are represented by fish as a bioindicator of the quality of the habitat of an aquatic flow area. The relation between abiotic and biotic characteristics is represented by the suitability curves of the individual fish species. Specifying the suitability curves is most challenging part of the RHABSIM model. Each species of fish (or other bioindicator) prefers certain combinations of abiotic environmental parameters. These parameters, for example, can be the flow velocity, depth, cover possibilities for the fish, type of bottom substrate, or water 
temperature or quality. The suitability curves for the depth and flow velocity are the most typical and most used curves. These curves are continuous since the parameters of the depth and flow velocity can be interpolated between each computational node of the model. It is necessary to emphasize that a change in flow also changes the suitability curves, similarly as in the work of Jager and Pert (1997). Therefore, during each ichthyological survey, the flow is determined using the hydrometry, and the suitability curve is recalculated to $\mathrm{Q}_{365}$. The suitability curves of all the reference reaches for the depths are shown in Figure 5 and for the flow velocity in Figure 6.

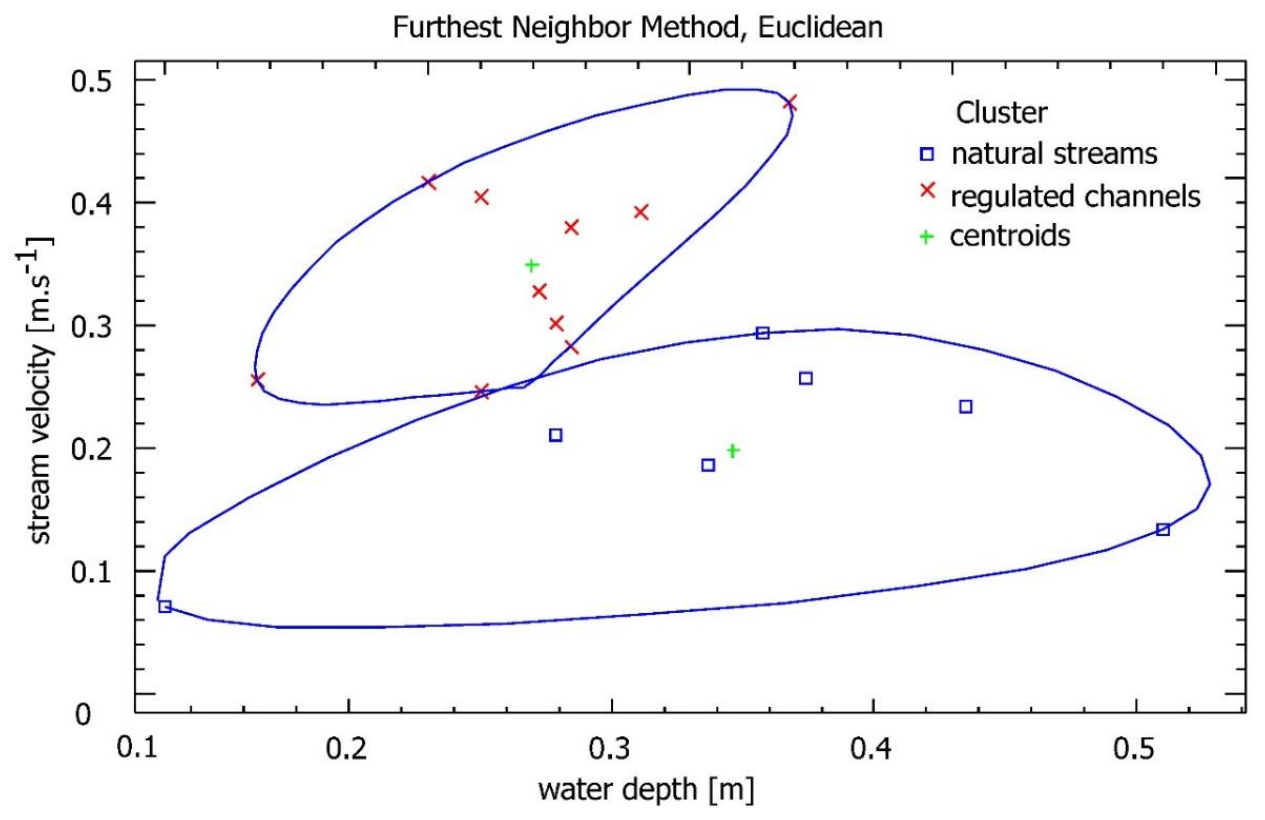

Figure 4. The occurrence of the brown trout at the individual depths and flow velocities

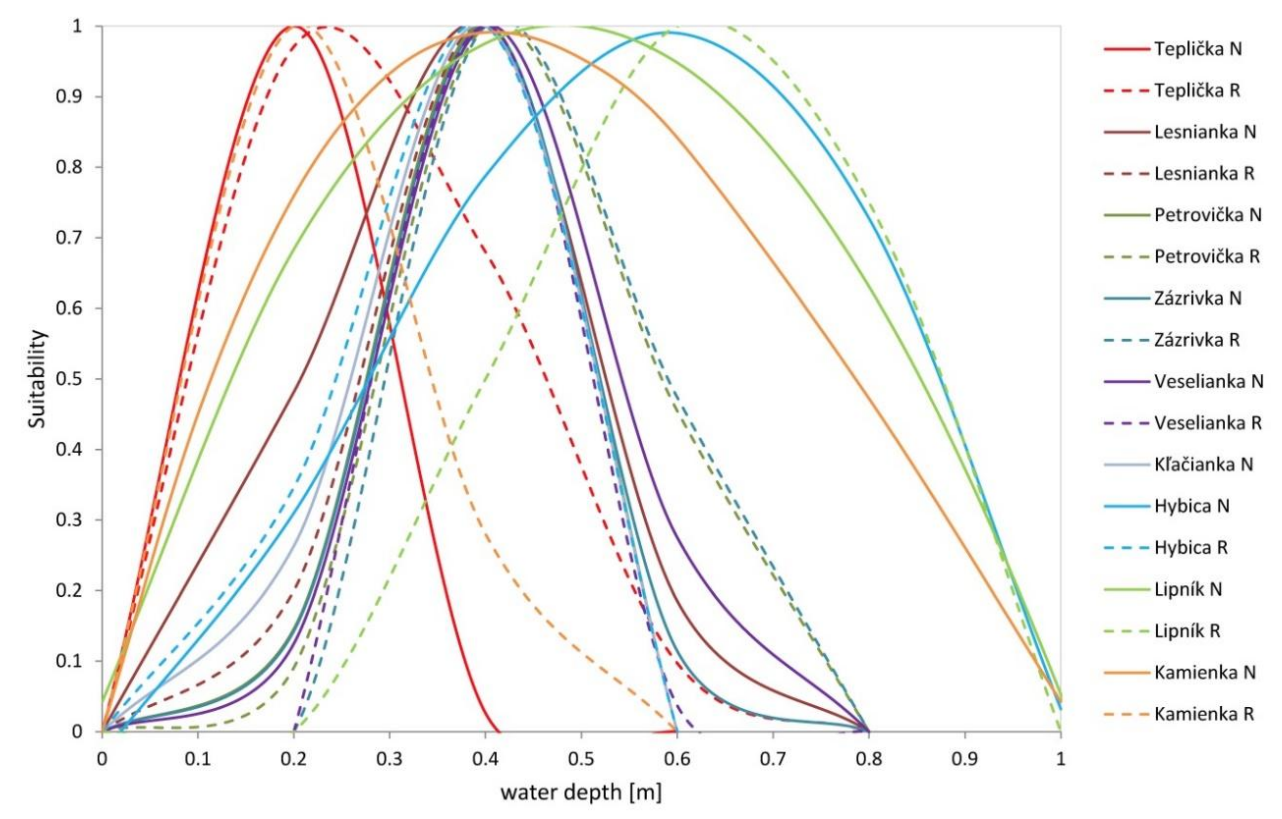

Figure 5. Suitability curves for the depths for the brown trout in the reference reaches of the stream 


$$
-5902-
$$

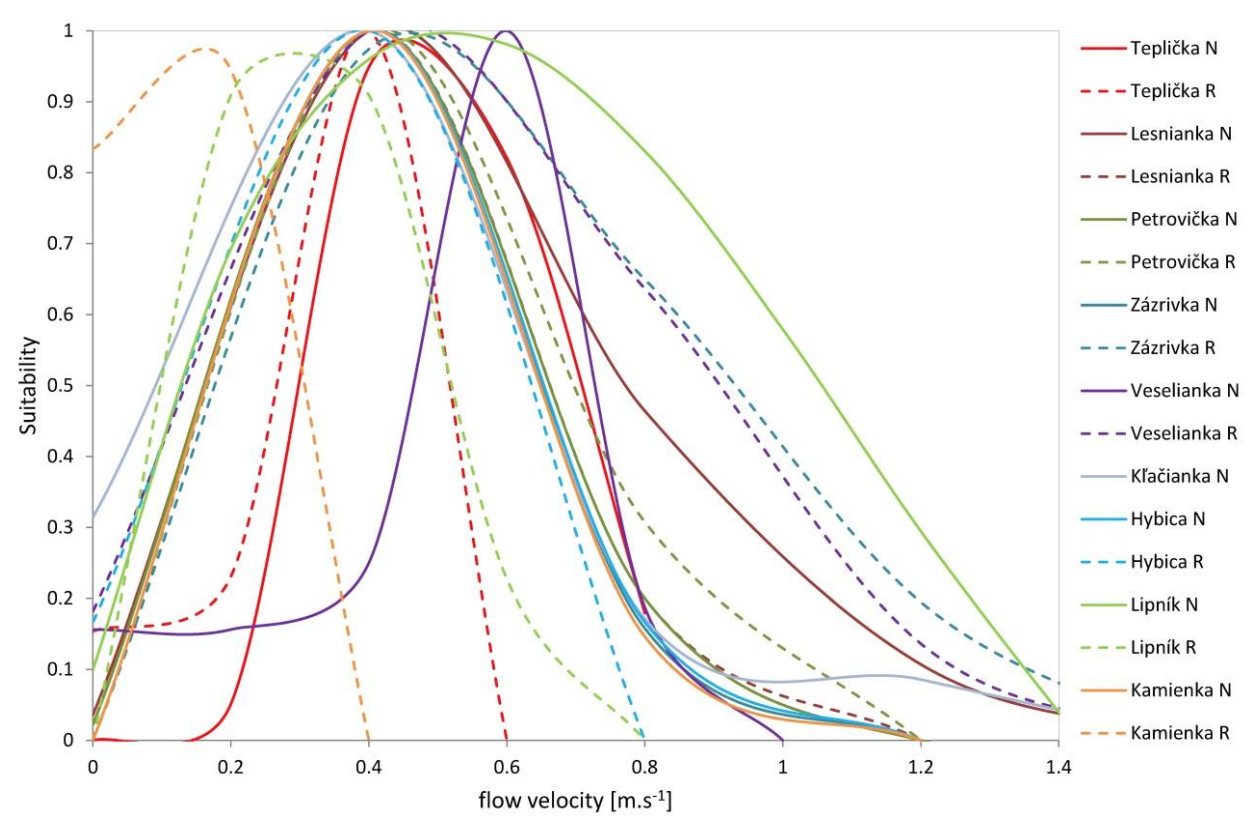

Figure 6. Suitability curves for the velocity for the brown trout in the reference reaches of the stream

\section{Relationship between the abiotic and biotic characteristics of the stream}

The previous evaluation is only based on the basic characteristics of the stream depth and flow velocity along with the occurrence of the representative fish species. Further, the morphological and hydraulic characteristics of the channel were assessed in relation to the fish preferences of the habitat, which are represented by suitability curves. The morphological and hydraulic characteristics of the channel are represented by the constant of the geometric and dynamic similarity M (Eq. 1; Grišanin, 1981):

$$
M=\frac{R(g \cdot B)^{\frac{1}{4}}}{Q^{\frac{1}{2}}}
$$

where:

$R \quad$ the hydraulic radius [m]

$g \quad$ the gravitational acceleration $\left[\mathrm{m} . \mathrm{s}^{-2}\right]$

$B \quad$ the channel width at the water level [m]

$Q \quad$ the flow $\left[\mathrm{m}^{3} \cdot \mathrm{s}^{-1}\right]$

$M$ a more detailed description of this parameter (dimensionless) is given in Grišanin (1981).

The peaks of the suitability curves were compared, i.e., the location with the largest occurrence of the given species at a certain depth and flow velocity. These values are listed as the velocity parameter $\left(P_{v}\right)$ and the depth parameter $\left(P_{d}\right)$. An important factor was the selection of a suitable representative fish species. Brown trout, which occurred in all the observed streams, is the most representative, and is very responsive to the morphology of the stream, was selected. 
To evaluate the correlation relationship, the Pearson's correlation coefficient $r$ was used. The interpretation of $r$ is a very common problem. According to Cohen (1988), the following evaluation of the correlation ratio is stated: A correlation below 0.1 is considered trivial, $0.1-0.3$ small, 0.3 - 0.5 mean, and above 0.5 , large. The correlation of $0.7-0.9$ is often referred to as very large, and $0.9-1$ is almost perfect. $P_{v}$ and $P_{d}$ were tested to $M$ (Table 3$)$.

Table 3. Comparison of the Pearson correlation coefficient ( $r)$ for the brown trout between the following variables: velocity parameter $\left(P_{v}\right)$, depth parameter $\left(P_{d}\right)$, the $M$-factor

\begin{tabular}{c|c|c}
\hline & $\boldsymbol{P}_{\boldsymbol{v}}-\boldsymbol{M}$ & $\boldsymbol{P}_{\boldsymbol{d}}-\boldsymbol{M}$ \\
\hline$r_{\text {All the watercourses }}$ & 0.06 & 0.14 \\
$r_{\text {Regulated channels }}$ & 0.64 & 0.28 \\
$r_{\text {Natural channels }}$ & 0.13 & 0.52 \\
\hline
\end{tabular}

The correlation coefficient $r$ was not confirmed in the case of the file created by all the flows $\left(P_{v}-M=0.06\right.$ and $\left.P_{d}-M=0.14\right)$. Therefore, the file was divided into two files: regulated streams and natural streams. In both files, the same parameters were correlated (Table 3). For the regulated streams the relationship between $P_{v}$ and $M$ equals 0.64, which can be characterized as a large degree of dependence; for the $P_{d}$ and $M$ relationship $=0.28$, which indicates an indirect relationship. For natural flows, the relation $P_{d}$ and $M=0.52$, i.e., shows a strong dependence, and for the $P_{v}$ and $M$ relationship $=0.13$, which is a small dependence.

\section{Discussion}

There is plenty of information about the effect of river regulation on ichthyofauna (Bovee, 1982, 1986; Booker and Dunbar, 2004; Parasiewicz and Walker, 2007). Most fish species prefer certain combinations of water depth, flow velocity, bedding material and hiding possibilities. Information about the influence of water flow rate and depth of water on habitat preference is also sufficient, for example in Macura et al. (2016) or in Wilding et al. (2014) where the authors stated that for several years, eco-hydraulic research has been focused on the effects of velocity and depth on the channel habitats of fish and other aquatic species. Applications of many models, such as IFIM, have shown that the water current can provide a series of speed and depth combinations that support a wide variety of species during their lifetime.

Previous studies have confirmed the correlation between suitability curve characteristics and flow hydraulics, particularly in relation to depth and water velocity (Macura et al., 2012; Davey et al., 2011). The flow velocity and the depth of water are the basic hydraulic characteristics that are interconnected. Therefore, the article analyzes the impact of the hydraulic flow on the quality of the aquatic habitat. Flow Hydraulics is represented by a constant of geometric and dynamic similarity $M$ and the preference of the habitat by ichthyofauna is represented by $P_{d}$ and $P_{v}$.

The results presented in Table 3 can be explained in relation to the morphology of the channel and the habitat preference of the brown trout as follows:

The brown trout does not have a suitable habitat in regulated rivers during small flows. Trout is only present in a regulated river during migration (in the summer it is a 


$$
\text { - } 5904 \text { - }
$$

food migration), when trout is guided by the flow velocity. This responds to the strong correlation of $P_{v}$ and $M$.

In natural streams trout prefer cover places with a sufficient depth. The velocity of the flow is not decisive in areas with greater depths, as there is usually a low velocity in these areas. This matches with the significant correlation of $P_{d}$ and $M$. The evaluated results directly confirmed the sensitivity of trout as a bioindicator to habitat parameters that are dominant in the characteristic reaches.

The results of the statistical evaluation show a clear division. Overall, it can be said that the basic stream characteristics indicated by the brown trout clearly divided the whole set for the regulated and natural streams.

Even in this case it has been confirmed that trout is a suitable bioindicator of the environment because it responds sensitively to changes in flow rates and flow depths (Hooper, 1973; Shirvell and Dungey, 1983; Reiser and Wesche, 1976; Macura et al., 2012, 2018).

\section{Conclusion}

Based on the current research results on the selected reference reaches of mountain watercourses in Slovakia, it follows that the changes caused by the topography of the channel and flow rates are well described by the relationship between the fish population and the characteristics of the habitat. The results from the cluster analysis and correlation analysis show the same trends. In particular, it can be said that the brown trout sensitively responds to abiotic characteristics such as the channel's morphology, flow velocity and depth and the biotic characteristics represented by the suitability curves.

Using these results it is possible to evaluate the impact of the proposed restoration measures. Such a process will greatly contribute to the quality of the restoration of the stream.

Acknowledgements. We thank the Slovak Research and Development Agency for the support of Project no. APVV-16-0253.

\section{REFERENCES}

[1] Avery-Gomm, S., Rosenfeld, J. S., Richardson, J. S., Pearson, M. (2014): Hydrological drought and the role of refugia in an endangered riffle-dwelling fish, Nooksack dace (Rhinichthys cataractae ssp.). - Canadian Journal of Fisheries and Aquatic Sciences 71: 1625-1634. DOI: 10.1139/cjfas-2013-0585.

[2] Ayllón, D., Almodóvar, A., Nicola, G. G., Elvira, B. (2009): Interactive effects of cover and hydraulics on brown trout habitat selection patterns. - River Res. Appl. 25(8): 10511065. DOI: 10.1002/rra.1215.

[3] Bockelmann, B. N., Fenrich, E. K., Lina, B., Falconer, R. A. (2004): Development of an ecohydraulics model for stream and river restoration. - Ecological Engineering 22: 227235. DOI: 10.1016/j.ecoleng.2004.04.003.

[4] Booker, D. J., Dunbar, M. J. (2004): Application of physical habitat simulation (PHABSIM) modelling to modified urban river channels. - River Research and Applications 20: 167-183. DOI: 10.1002/rra.742. 
[5] Bovee, K. D. (1982): A Guide to Stream Habitat Analysis Using the Instream Flow Incremental Methodology. - Instream Flow Information Paper 12. FWS /OBS-82 26. USDI Fish and Wildlife Service, Office of Biology Services: Washington, DC.

[6] Bovee, K. D. (1986): Development and Evaluation of Habitat Suitability Criteria for Use in the Instream Flow Incremental Methodology. - Instream Flow Information Paper 21. FWS/OBS-86/7. USDI Fish and Wildlife Service, Office of Biology Services: Washington, DC.

[7] Bovee, K. D., Lamb, B. L., Bartholow, J. M., Stalnaker, C. B., Taylor, J., Henriksen, J. (1998): Stream Habitat Analysis Using the Instream Flow Incremental Methodology. Information and Technology Report USGS/BRD/ITR-1998-0004. Geological Survey BRD, Fort Collins, CO.

[8] Carlson, A. K., Taylor, W. W., Schlee, K. M., Zorn, T. G., Infante, D. M. (2015): Projected impacts of climate change on stream salmonids with implications for resiliencebased management. - Ecology of Freshwater Fish. DOI: 10.1111/eff.12267.

[9] Carnie, R., Tonina, D., McKean, J. A., Isaak, D. (2016): Habitat connectivity as a metric for aquatic microhabitat quality: application to Chinook salmon spawning habitat. Ecohydrol. 9: 982-994. DOI: 10.1002/eco.1696.

[10] Cheek, C. A., Taylor, C. M. (2016): Salinity and geomorphology drive long-term changes to local and regional fish assemblage attributes in the lower Pecos River, Texas. Ecology of Freshwater Fish 25: 340-351. DOI: 10.1111/eff.12214.

[11] Cohen, J. (1988): Statistical power analysis for the behavioral sciences. 2nd ed. Lawrence Earlbaum Associates, Hillsdate, NJ.

[12] Conallin, J., Boegh, E., Jensen, J. K. (2010): Instream physical habitat modelling types: an analysis as stream hydromorphological modelling tools for EU water resource managers. - Int. J. River Basin Manag. 8(1): 93-107. DOI: 10.1080/15715121003715123.

[13] Copp GH. (1992): Comparative microhabitat use of cyprinid larvae and juveniles in a lotic floodplain channel. - Environmental Biology of Fishes 33: 181-193.

[14] Davey, A. J. H., Booker, D. J., Kelly, D. J. (2011): Diel variation in stream fish habitat suitability criteria: implications for instream flow assessment. - Aquatic Conserv: Mar. Freshw. Ecosyst. 21: 132-145. DOI: 10.1002/aqc.1166.

[15] Galbraith, H. S., Blakeslee, C. J., Cole, J. C., Talbert, C. A., Maloney, K. O. (2016): Evaluating methods to establish habitat suitability criteria: a case study in the Upper Delaware River Basin, USA. - River Res. Applic. 32: 1765-1775. DOI: 10.1002/rra.3025.

[16] Galie, A. C., Moldoveanu, M., Antonaru, O. (2017): Hydromorphological assessment of atypical lowland river -Rromanian litoral basin case study. - Carpathian Journal of Earth and Environmental Sciences 12(1): 161-169.

[17] Gibson, S. A., Pasternack, G. B. (2016): Selecting between one-dimensional and twodimensional hydrodynamic models for ecohydraulic analysis. - River Res. Applic. 32: 1365-1381. DOI: 10.1002/rra.2972.

[18] Grišanin, K. V. (1981): Riverbed Dynamics (in Russian: Dinamika ruslovych potokov). Izd. Gidrometeoizdat, Leningrad.

[19] Holm, C. F., Armstrong, J. D., Gilvear, D. J. (2001): Investigating a major assumption of predictive instream habitat models: is water velocity preference of juvenile Atlantic salmon independent of discharge? - Journal of Fish Biology 59: 1653-1666. DOI: 10.1111/j.1095-8649.2001.tb00228.x.

[20] Hooper, D. (1973): Evaluation of the Effects of Flows on Trout Stream Ecology. Pacific Gas and Electric Company, Dept. Of Engineering Research, Emeryville, California.

[21] Horváth, J., Gregušová, H. (1999): Clustered Analysis and Projective Methods. Mathematical Statistics and Numerical Mathematics and Their Applications. - Faculty of Civil Engineering, Slovak University of Technology, Bratislava, pp. 205-237. 
[22] Jager, H. I., Pert, E. G. (1997): Comment testing the independence of microhabitat preferences and flow (Part 2). - Transaction of the American Fisheries Society 126: 537540. DOI: 10.1577/1548-8659-126.3.537.

[23] Keeley, E. R., Campbell, S. O., Kohler, A. E. (2015): Bioenergetic calculations evaluate changes to habitat quality for salmonid fishes in streams treated with salmon carcass analog. - Canadian Journal of Fisheries and Aquatic Sciences 73: 819-831. DOI: 10.1139/cjfas-2015-0265.

[24] Lambert, T. R., Hanson, D. F. (1989): Development of habitat suitability criteria for trout in small streams. - Regulated Rivers: Research \& Management 3: 291-303. DOI: 10.1002/rrr.3450030128.

[25] Lamouroux, N., Capra, H., Pouilly, M., Souchon, Y. (1999): Fish habitat preferences in large streams of southern France. - Freshwater Biology 42: 673-687. DOI: 10.1046/j.1365-2427.1999.00521.x.

[26] Lopes, L., Do Carmo, J., Cortes, R., Oliveira, D. (2004): Hydrodynamics and water quality modelling in a regulated river segment: application on the instream flow definition. - Ecological Modelling 173: 197-218. DOI: 10.1016/j.ecolmodel.2003.07.009.

[27] Macura, V., Škrinár, A., Kalúz, K., Jalčovíková, M., Škrovinová, M. (2012): Influence of the morphological and hydraulic characteristics of mountain streams on fish habitat suitability curves. - River Research and Applications. DOI: 10.1002/rra.1518.

[28] Macura, V., Štefunková, Z., Škrinár, A. (2016): Determination of the effect of water depth and flow velocity on the quality of an in-stream habitat in terms of of climate change. - Advances in Meteorology 2016: Article ID 4560378. DOI: 10.1155/2016/4560378.

[29] Macura, V., Štefunková, Z., Majorošová, M., Halaj, P., Škrinár, A. (2018): Influence of discharge on fish habitat suitability curves in mountain watercourses in IFIM methodology. - J. Hydrol. Hydromech 66: 12-22. DOI: 10.1515/johh-2017-0044.

[30] Marsili-Libelli, S., Giusti, E., Nocita, A. (2013): A new instream flow assessment method based on fuzzy habitat suitability and large scale river modelling. - Environ. Model. Softw. 41: 27-38. DOI: 10.1016/j.envsoft.2012.10.005.

[31] Parasiewicz, P., Walker, J. D. (2007): Comparison of Meso-HABSIM with two microhabitat models (PHABSIM and HARPHA). - River Res. Applic. 23: 904-923. DOI: 10.1002/rra.1043.

[32] Payne, T. R. (1998): RHABSIM 2.1 for DOS and Windows User's Manual. - Fisheries Biology, Consulting and Software Publishing, Agrata, CA.

[33] Piniewski, M., Prudhomme, C., Acreman, M. C., Tylec, L., Oglęcki, P., Okruszko, T. (2016): Responses of fish and invertebrates to floods and droughts in Europe. Ecohydrol. DOI: 10.1002/eco.1793.

[34] Pont, D., Hugueny, B., Beier, U., Goffaux, D., Melcher, A., Noble, R., Rogers, C., Roset, N., Schmutz, S. (2006): Assessing river biotic condition at a continental scale: a European approach using functional metrics and fish assemblages. - Journal of Applied Ecology 43: 70-80. DOI: 10.1111/j.1365-2664.2005.01126.x.

[35] Reiser, D. W., Wesche, T. A. (1976): Determination of physical and hydraulic preferences of brown and brook trout in the selection of spawning locations. - University of Wyoming, Water Resources Research Institute. Water Resources Series 64.

[36] Roni, P., Beechie, T., Pess, G., Hanson, K. (2014): Wood placement in river restoration: fact, fiction, and future direction. - Canadian Journal of Fisheries and Aquatic Sciences 72: 466-478. DOI: 10.1139/cjfas-2014-0344.

[37] Rosenfeld, J. S., Ptolemy, R. (2012): Modelling available habitat versus available energy flux: do PHABSIM applications that neglect prey abundance underestimate optimal flows for juvenile salmonids? - Canadian Journal of Fisheries and Aquatic Sciences 69: 19201934. DOI: $10.1139 / \mathrm{f} 2012-115$.

[38] Santiago, J. M., García de Jalón, D., Alonso, C., Solana, J., Ribalaygua, J., Pórtoles, J., Monjo, R. (2016): Brown trout thermal niche and climate change: expected changes in 
the distribution of cold-water fish in central Spain. - Ecohydrol. 9: 514-528. DOI: 10.1002/eco.1653.

[39] Scholten, M. (2003): Efficiency of point abundance sampling by electro-fishing modified for short fishes. - J. Appl. Ichtyol. 19: 265-244. DOI: 10.1046/j.1439-0426.2003.00505.x.

[40] Shields, F. D., Knight, S. S., Cooper, C. M. (1997): Rehabilitation of warmwater stream ecosystems following channel incision. - Ecological Engineering 8: 93-116.

[41] Shirvell, C. S., Dungey, R. G. (1983): Microhabitats chosen by brown trout for feeding and spawning in rivers. - Transactions of the American Fisheries Society 112(3): 355367.

[42] Shuler, S. W., Nehring, R. B. (1994): Using the Physical Habitat Simulation Model to evaluate a stream habitat enhancement project. - Rivers 4: 175-193.

[43] Sokal, R. R., Michener, C. D. (1958). A statistical method for evaluating systematic relationships. - Univ. Kansas Sci Bull. 38: 1409-1438.

[44] Stalnaker, C., Lamb, B. L., Henriksen, J., Bovee, K., Bartholow, J. (1995): The Instream Flow Incremental Methodology. A Primer for IFIM. - Biological Science Report 29. National Biological Service, US Dept. of Interior, Washington, DC.

[45] Townsend, C. R., Hildrew, A. G. (1994): Species traits in relation to habitat templet for river systems. - Freshwater Biology 31: 265-275.

[46] Turner, D., Bradford, M. J., Venditti, J. G., Peterman, R. M. (2016): Evaluating uncertainty in physical habitat modelling in a high-gradient mountain stream. - River Res. Applic. 32: 1106-1115. DOI: 10.1002/rra.2915.

[47] Vannote, R. L., Minshall, G. W., Cummins, K. W., Sedell, J. R., Cushing, C. E. (1980): The river continuum concept. - Canadian Journal of Fisheries and Aquatic Sciences 37(1): 130-137.

[48] Wilding, T. K., Bledsoe, B., Poff, N. L., Sanderson, J. (2014): Predicting habitat response to flow using generalized habitat models for trout in Rocky Mountain streams. - River Res. Applic. 30: 805-824. DOI: 10.1002/rra.2678.

[49] Williams, J. G. (2001): Tripping over spatial scales: a comment on Guay et al. 2000. Canadian Journal of Fisheries and Aquatic Sciences 58: 2105-2107.

[50] Zhang, H., Wang, C. Y., Wu, J. M., Du, H., Wei, Q. W., Kang, M. (2016): Physical habitat assessment of a remaining high-biodiversity reach of the upper Yangtze river, China. - Applied Ecology and Environmental Research 14: 129-143. DOI: http://dx.doi.org/10.15666/aeer/1401_129143. 